University of Nebraska - Lincoln

DigitalCommons@University of Nebraska - Lincoln

Papers in Veterinary and Biomedical Science

Veterinary and Biomedical Sciences,

Department of

November 2006

\title{
Anti-capsular antibodies activate killing of Escherichia coli 08:K87 by the alternate complement pathway in porcine serum
}

\author{
N. M. Clark \\ University of Nebraska - Lincoln \\ E. M. Berberov \\ University of Nebraska - Lincoln \\ M. Wang \\ University of Nebraska Medical Center, Omaha, NE \\ Rodney A. Moxley \\ University of Nebraska - Lincoln, rmoxley1@unl.edu
}

Follow this and additional works at: https://digitalcommons.unl.edu/vetscipapers

Part of the Veterinary Medicine Commons

Clark, N. M.; Berberov, E. M.; Wang, M.; and Moxley, Rodney A., "Anti-capsular antibodies activate killing of Escherichia coli 08:K87 by the alternate complement pathway in porcine serum" (2006). Papers in Veterinary and Biomedical Science. 75.

https://digitalcommons.unl.edu/vetscipapers/75

This Article is brought to you for free and open access by the Veterinary and Biomedical Sciences, Department of at DigitalCommons@University of Nebraska - Lincoln. It has been accepted for inclusion in Papers in Veterinary and Biomedical Science by an authorized administrator of DigitalCommons@University of Nebraska - Lincoln. 
Published in Veterinary Immunology and Immunopathology 114:1-2 (November 15, 2006), pp. 185-191. doi:10.1016/j.vetimm.2006.07.008 Copyright (C) 2006 Elsevier B.V. Used by permission. http://www.sciencedirect.com/science/journal/01652427

Submitted February 6, 2006; revised July 7, 2006; accepted July 10, 2006; published online August 21, 2006.

\title{
Anti-capsular antibodies activate killing of Escherichia coli O8:K87 by the alternate complement pathway in porcine serum
}

\author{
N. M. Clark ${ }^{1, *}$, E. M. Berberov ${ }^{1, \dagger}$, M. Wang ${ }^{2, \ddagger}$, and R. A. Moxley ${ }^{1, \S}$ \\ ${ }^{1}$ Department of Veterinary and Biomedical Sciences, University of Nebraska-Lincoln, Fair Street and East Campus Loop, \\ Lincoln, NE 68583-0905, USA \\ ${ }^{2}$ Department of Pharmaceutical Sciences, College of Pharmacy, University of Nebraska Medical Center, Omaha, NE \\ 68198-6025, USA \\ * Present address: Department of Pathology and Microbiology, 983135 Nebraska Medical Center, Omaha, NE 68198-3135, \\ USA. \\ $\dagger$ Present address: Vaccine and Infectious Disease Organization, University of Saskatchewan, 120 Veterinary Road, Saskatoon, \\ Sask. S7N 5E3, Canada. \\ $\$$ Present address: Department of Applied Chemistry, College of Sciences West Campus, China Agricultural University, Beijing \\ 100094, PR China. \\ $\S$ Corresponding author. Tel.: +1 402472 8460; fax: +1 4024729690.
}

\begin{abstract}
Enterotoxigenic Escherichia coli (ETEC) strains that produce K88 (F4) fimbria are important causes of diarrhea and post-diarrheal septicemia in swine. ETEC O8:K87, a serotype represented by a number of these strains, is typically serum resistant. Strain-specific antibodies are known to activate alternative C pathway-mediated killing of other serum-resis$\operatorname{tant} E$. coli [Hill, A.W., Shears, A.L., Hibbitt, K.G., 1978. The requirement of specific antibody for the killing of $E$. coli by the alternate complement pathway in bovine serum. Immunology 34, 131-136], but their antigenic targets have not been determined. We tested the hypothesis that anti-K87 antibodies activate alternative pathway-mediated killing of ETEC O8: K87. Pigs were immunized with ETEC O8:K87 strain 2534-86 cells or purified K87 polysaccharide. Post-, but not pre-immunization sera killed 2534-86 cells, and absorption with 2534-86 cells or by K87 affinity chromatography eliminated bactericidal activity. Complementation of absorbed serum with anti-K87 antibodies restored bactericidal activity, confirming the ability of these antibodies to activate C-mediated serum killing. Serum from age-matched, non-vaccinated control pigs also killed 2534-86. This activity was eliminated by absorption with $2534-86$ cells, but not K87 affinity chromatography, indicating that specific non-capsular antibodies are also able to activate C-mediated killing. In all cases, Mg-EGTA-treated serum was as effective as non-treated serum in killing, suggesting that bactericidal activity was mediated predominantly if not exclusively via the alternative $\mathrm{C}$ pathway.
\end{abstract}

Keywords: Escherichia coli, Capsule, Polysaccharide, Alternative complement pathway, Enterotoxigenic E. coli, Pig, Porcine, Serum resistance, K87, Anti-capsular antibodies

\section{Introduction}

Enterotoxigenic Escherichia coli (ETEC) is an important cause of diarrhea and post-diarrheal septicemia in pre- and post-weaned pigs (Berberov et al., 2004). ETEC $\mathrm{O} 8: \mathrm{K} 87$, a serotype that includes some of these strains, is typically serum resistant, but this phenotype is lost in spontaneous acapsular $\left(\mathrm{K} 87^{-}\right)$mutants (Stawski et al., 1990). Strain-specific antibodies are known to activate alternative $\mathrm{C}$ pathway-mediated killing of serum-resistant E. coli O149:K91:H10:F4ac by bovine serum, but their antigenic targets have not been determined (Hill 
et al., 1978). In the present study, we hypothesized that anti-K87 antibodies activate alternative $\mathrm{C}$ pathway-mediated killing of ETEC O8:K87 in porcine serum and removal of these specific antibodies mitigates this activity. We provide evidence herein supporting this hypothesis; we also found that these antibodies are highly prevalent in the swine population, and that specific non-capsular antibodies also activate alternative pathway-mediated killing.

\section{Materials and methods}

\subsection{Bacterial strains}

Strain 2534-86 (ETEC; O8:K87:NM:F4ac) was originally isolated from a piglet with diarrhea and septicemia, and causes these clinical manifestations in gnotobiotic piglets (Berberov et al., 2004). This strain was used to immunize animals against $E$. coli cells expressing K87 capsular polysaccharide, and was a source of the latter for purified antigen. E. coli $\mathrm{O} 8: \mathrm{K}^{-}$strain F1321 (Meier and Mayer, 1985) and E. coli strain K12:F4ac (Berberov et al., 2004) were used to test the specificity of the indirect ELISA for K87 antibodies. E. coli strain DH5 $\alpha$ was used as a positive control to test for $\mathrm{C}$-mediated bactericidal activity of serum.

\subsection{Isolation and purification of K87 capsular poly- saccharide antigen}

Purified K87 capsular polysaccharide (PP) was isolated by phenol-water extraction (Jann, 1985) from strain 2534-86 cultures. Glucose concentration (Saha and Brewer, 1994) was $95.46 \%$ of the calculated yield per gram, suggesting that the extract was K87 polysaccharide. No evidence of protein, LPS or nucleic acid contamination was found; purity was confirmed by ${ }^{1} \mathrm{H}$ nuclear magnetic resonance spectroscopy ( $\left.{ }^{1} \mathrm{H} \mathrm{NMR}\right)$ of the extract conducted in $\mathrm{D}_{2} \mathrm{O}$. Chemical shifts and coupling patterns were identical to the $\mathrm{K} 87$ spectrum reported by Parolis et al. (1990).

\section{3. ${ }^{1} \mathrm{H}$ NMR studies}

${ }^{1} \mathrm{H}$ NMR spectroscopy was conducted on a Varian Unity $500 \mathrm{MHz}$ spectrometer at $25^{\circ} \mathrm{C}$. A presaturation sequence was utilized to reduce the intensity of the $\mathrm{H}_{2} \mathrm{O}$ peak which served as an internal standard at $\delta$ 4.773. ${ }^{1} \mathrm{H}$ NMR $\left(\delta, \mathrm{ppm}, \mathrm{D}_{2} \mathrm{O}\right) 1.307$ (Mc), 1.972, $1990,2.083\left(\mathrm{CH}_{3} \mathrm{CO}\right), 3.20-3.30,3.42-3.58,3.60-$ $4.05,4.10-4.20,4.35-4.58,4.62-4.75,4.80-4.90$, $5.15-5.21,5.43-5.52$.

\subsection{Preparation of formalin-treated strain 2534-86 cells for immunization}

Formalinized E. coli strain 2534-86 cells for immunization were prepared using the methods of Gross and Rowe (1985). Bacteria were washed twice by centrifugation and resuspension in $0.9 \%$ saline, and resuspended in $0.3 \%(\mathrm{v} / \mathrm{v})$ solution of commercial $10 \%$ neutral-buffered formalin in $0.9 \%$ saline at a concentration equivalent to $1.0 \times 10^{9} \mathrm{CFU} / \mathrm{ml}$.

\subsection{Experimental animals}

$\mathrm{BALB} / \mathrm{c}$ mice (6-8-week-old adult females; $n=16$ ), specific pathogen-free (SPF) New Zealand White rabbits (5-6 month-old adult females; $n=2$ ), and cesarean-derived, colostrum-deprived, primary SPF purebred Yorkshire pigs $(n=10)$ were immunized against PP or 2534-86 cells. When pigs were 1 month old, seven were used for immunization, and three were nonvaccinated and kept in the same room as controls. Serum samples were obtained prior to the first immunization and at the conclusion of immunizations, at which time they were euthanatized and exsanguinated. Serum samples from 75 conventional pigs from 11 herds in five different counties in Nebraska were obtained to test for antibodies to K87; 40 pigs were 8 weeks old and 35 were 5-6 months old. Serum samples were stored at $-70{ }^{\circ} \mathrm{C}$ until used in assays. Animal experiments were approved by the UNL Institutional Animal Care and Use Committee.

\subsection{Immunization protocols}

Immunization protocols for PP and 2534-86 cells were developed by modification of standard procedures. Mice $(n=8)$ were primed i.p. with $100 \mu \mathrm{g}$ PP and $100 \mu \mathrm{l}$ complete Freund's adjuvant (CFA), and boosted twice i.p. with $50 \mu \mathrm{g}$ PP and $50 \mu \mathrm{l}$ incomplete Freund's adjuvant (IFA), or $(n=8)$ primed i.p. with $1.0 \times 10^{8} \mathrm{CFU}$ and $100 \mu \mathrm{l} \mathrm{CFA}$, and boosted twice i.p. with $1.0 \times 10^{8}$ $\mathrm{CFU}$ and $50 \mu \mathrm{l}$ IFA. Rabbits $(n=1)$ were primed s.c. with $150 \mu \mathrm{g}$ PP and $150 \mu \mathrm{l} \mathrm{CFA}$, and boosted twice s.c. with $75 \mu \mathrm{g}$ PP and $75 \mu$ IFA, or $(n=1)$ primed i.v. with $0.5 \times 10^{9} \mathrm{CFU}$, and boosted four times i.v. with $1.0-2.0 \times 10^{9} \mathrm{CFU}$. Pigs $(n=4)$ were primed s.c. with $200 \mu \mathrm{g}$ PP and $200 \mu \mathrm{l} \mathrm{CFA}$, and boosted twice s.c. with $100 \mu \mathrm{g}$ PP and $100 \mu \mathrm{l}$ IFA, or $(n=3)$ primed i.v. with $0.5 \times 10^{9} \mathrm{CFU}$, and boosted twice i.v. with $0.5 \times 10^{9}$ CFU. Cells used for the first dose given to the pigs were inadvertently boiled, although the remaining doses were not. 


\subsection{Indirect enzyme-linked immunosorbent assay (ELISA) to detect anti-K87 antibodies}

An indirect ELISA was developed using standard procedures to measure the titers of anti-K87 antibodies in sera. Polystyrene 96-well plates were coated with antigen, each well with $50 \mu 1$ of a PBS solution containing $10 \mathrm{ng}$ PP. Sera were diluted from 1:100 to $1: 204,800$ in wells of the plates. Goat anti-species IgG labeled with horseradish peroxidase was used as the secondary anti- body, with peroxide and $o$-phenylenediamine for color development. Absorption was measured at $490 \mathrm{~nm}$. The antibody titer was the highest dilution having an absorbance (mean \pm 1 S.E.M.) greater than the negative control (mean \pm 1 S.E.M.).

\subsection{Absorption of specific antibodies from serum}

Antibodies to K87 and other surface antigens on $E$. coli strains were absorbed from sera with bacteria us-
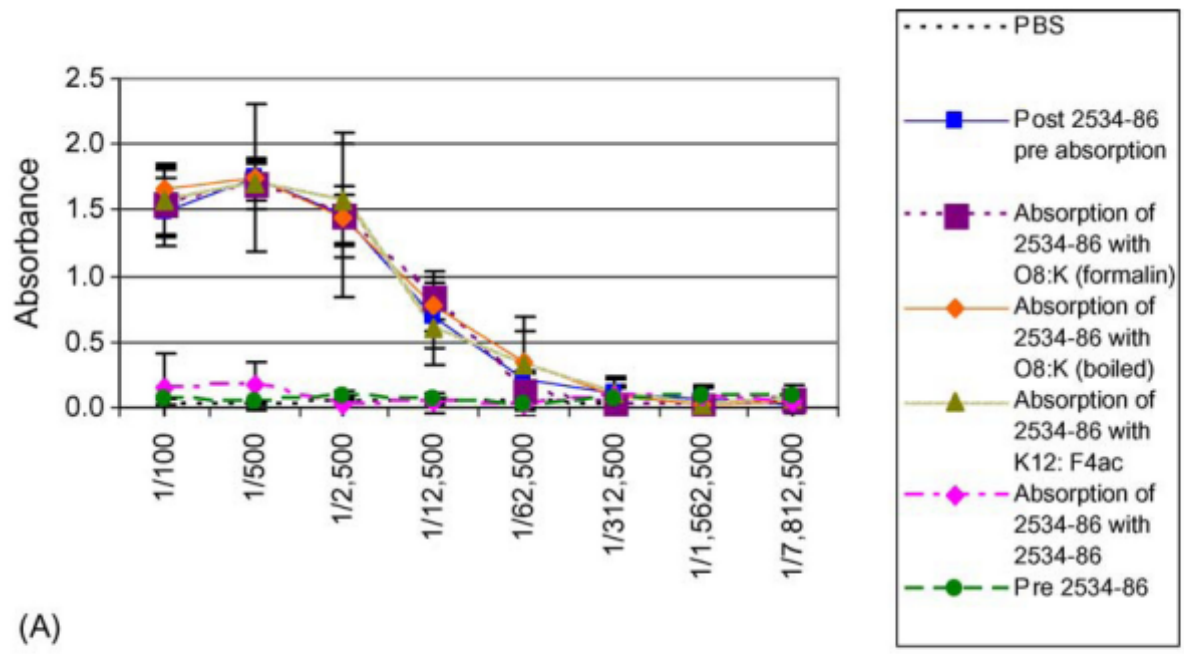

(A)
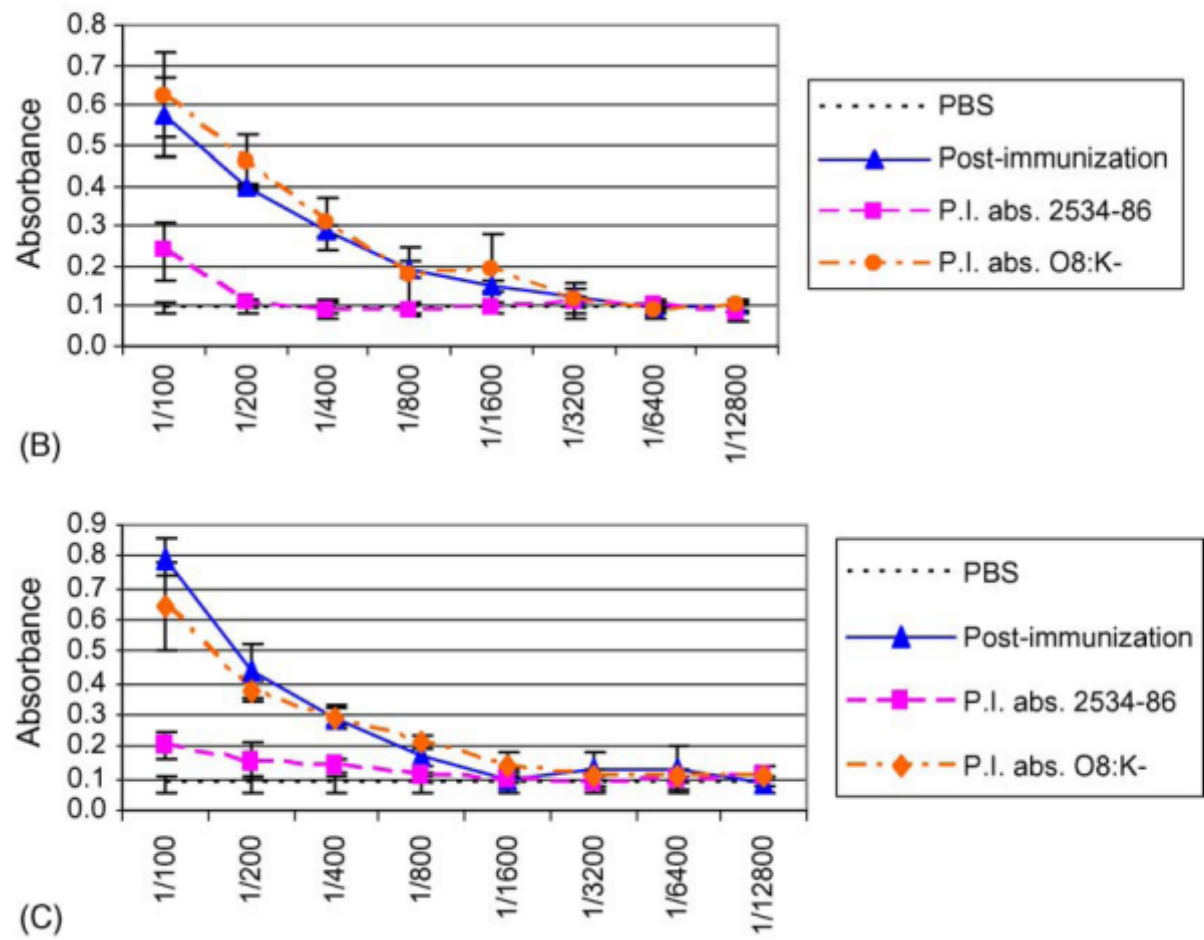

Figure 1. (A) Indirect ELISA for detection of anti-K87 antibodies. Serum from rabbit immunized with formalin-treated E. coli O8:K87 strain 2534-86 cells. Purified K87 polysaccharide (PP) was coated onto polyvinyl chloride microtiter plate wells, and serum dilutions from immunized animals were added. Binding of antibodies to the immobilized polysaccharide was detected by goat anti-species IgG labeled with horseradish peroxidase, and $o$-phenylenediamine substrate, and reactions were read at $490 \mathrm{~nm}$. The specificity of the assay for anti-K87 antibodies was validated by absorption with cells expressing F4ac fimbria, O8 antigen and other surface antigens commonly found on E. coli O8 bacteria. (B) Serum from primary SPF pigs immunized with formalinized 2534-86 cells and absorbed with 2534-86 or E. coli O8: $\mathrm{K}^{-}$strain F1321 cells. (C) Serum from primary SPF pigs immunized with PP and absorbed with 2534-86 or F1321 cells. 
ing standard procedures (Gross and Rowe, 1985), or by affinity chromatography using epoxy-activated Sepharose 6B beads (Amersham Pharmacia Biotech) coupled to PP. PP was added at a concentration of $400 \mu \mathrm{g} /$ $\mathrm{ml}$ and using a gel:buffer ratio of 1:2. Absorption control sera were prepared with a column containing Sepharose 6B beads not coupled to PP. Sera were passed through the column and absorbed antibodies were eluted with $0.1 \mathrm{M}$ sodium citrate ( $\mathrm{pH}$ 3.0). Two hundred microliters eluate fractions were collected and the $\mathrm{pH}$ adjusted to 7.5 with $1 \mathrm{M}$ Tris-HCL (pH 9.0). Fractions containing protein (bicinchoninic assay) were added to absorbed sera. All sera to which eluate was not added were diluted with an equal volume of buffer, and adjusted to $\mathrm{pH} 7.3$ in order to standardize test and control samples.

\subsection{Serum bactericidal assay}

Serum bactericidal assays were performed with pre- and post-immunization sera of primary SPF pigs immunized with PP or strain 2534-86 cells, and control pigs. Assays were performed with serum that was untreated, treated with $\mathrm{MgCl}_{2}$ and ethylene glycol tetraacetic acid $(\mathrm{Mg}-$ EGTA), and heat-inactivated $\left(56^{\circ} \mathrm{C}\right.$ for $30 \mathrm{~min}$; Burns and Hull, 1998). Buffered saline gelatin (BSG) with
$\mathrm{Mg}^{2+}(10$ or $20 \mathrm{mM} \mathrm{MgCl}$ ) and EGTA (10 or $20 \mathrm{mM}$ ) was added to serum.

\section{Results and discussion}

The indirect ELISA to detect anti-K87 antibodies was validated by absorption of serum from a rabbit immunized with 2534-86 cells using E. coli cells exposing O8, F4ac fimbria, and other surface antigens (Figure 1A). No reduction in titer occurred following absorption of postimmunization serum with formalinized strain F1321 $\left(\mathrm{O} 8: \mathrm{K}^{-}\right)$cells exposing $\mathrm{O} 8$ and other E. coli surface antigens or boiled cells exposing $\mathrm{O} 8$ antigen, or following absorption with formalinized K12:F4ac cells exposing F4ac fimbriae. However, absorption with formalinized 2534-86 cells exposing K87 antigen eliminated the titers. Immunization of mice with 2534-86 cells or PP caused seroconversion (data not shown). All conventional pigs tested were positive for antibodies to K87, with titers ranging from 1:6400 to $1: 204,800$. Immunization of colostrum-deprived, primary SPF pigs with 2534-86 cells and PP caused seroconversion to K87 antigen (Figure 1B and $\mathrm{C}$, respectively), whereas non-vaccinated age-matched (68-72-day-old) control pigs were seronegative (data not shown). Absorption of post-im-
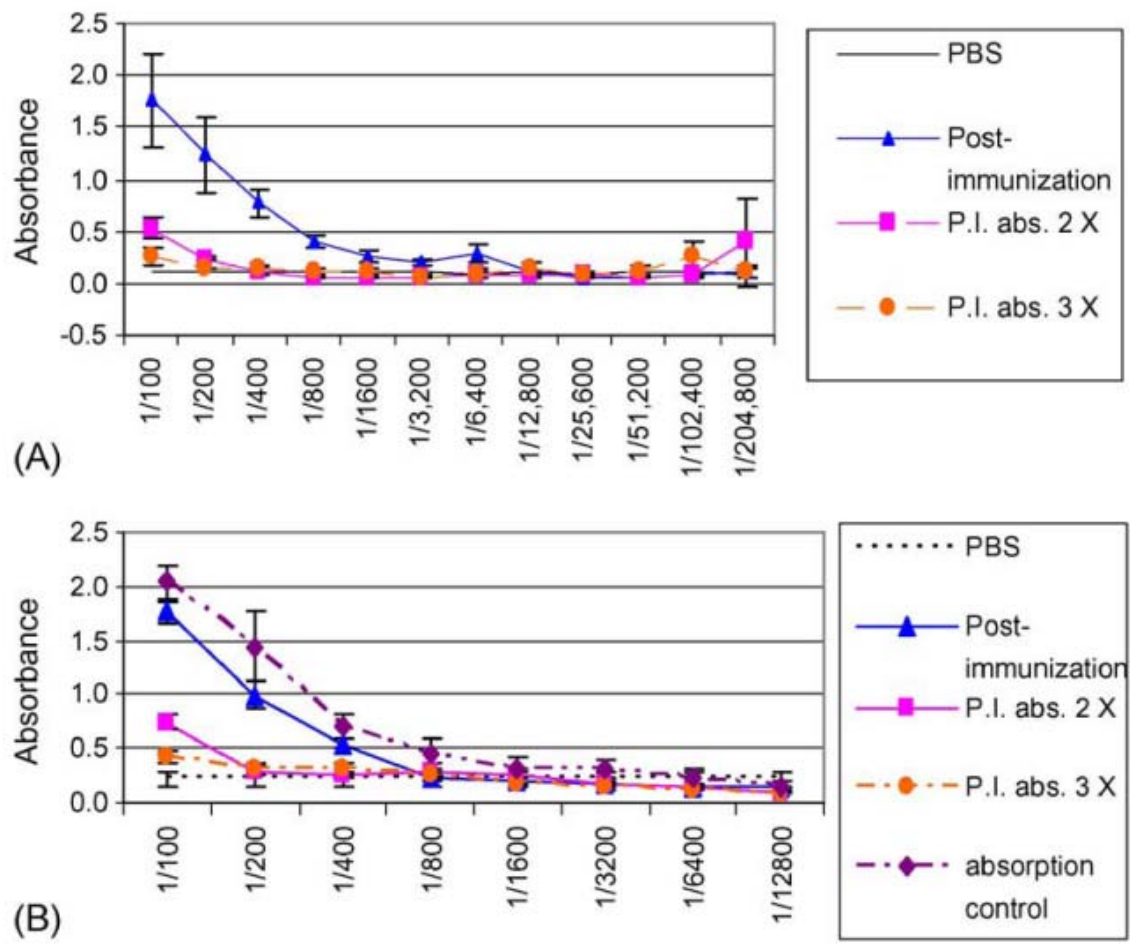

Figure 2. Indirect ELISA for detection of anti-K87 antibodies. (A) Serum from primary SPF pig immunized with formalin-treated strain 253486 cells. Serum was subjected to 2-3 cycles of affinity chromatography with Sepharose 6B beads coupled to K87 polysaccharide (PP), or Sepharose beads not coupled to PP. (B) Serum from primary SPF pig immunized with PP. Serum was subjected to 2-3 cycles of affinity chromatography with beads coupled or not to PP. 
munization pig sera with formalinized 2534-86 cells but not F1321 $\left(\mathrm{O} 8: \mathrm{K}^{-}\right)$cells eliminated the anti-K87 titers (data not shown). K87 affinity chromatography caused complete removal of detectable anti-K87 antibodies in sera from primary SPF pigs immunized with 2534-86 cells (Figure 2A) and PP (Figure 2B), whereas absorption control sera retained these antibodies.
To address whether anti-K87 antibodies specifically activate $\mathrm{C}$-mediated bactericidal activity, sera from primary SPF pigs immunized with formalinized 2534-86 cells or PP were tested in bactericidal assays against 2534-86 cells. Pre-immunization sera had no bactericidal activity after $3 \mathrm{~h}$ incubation, whereas sera from pigs immunized with formalinized 2534-86 cells or PP elicited
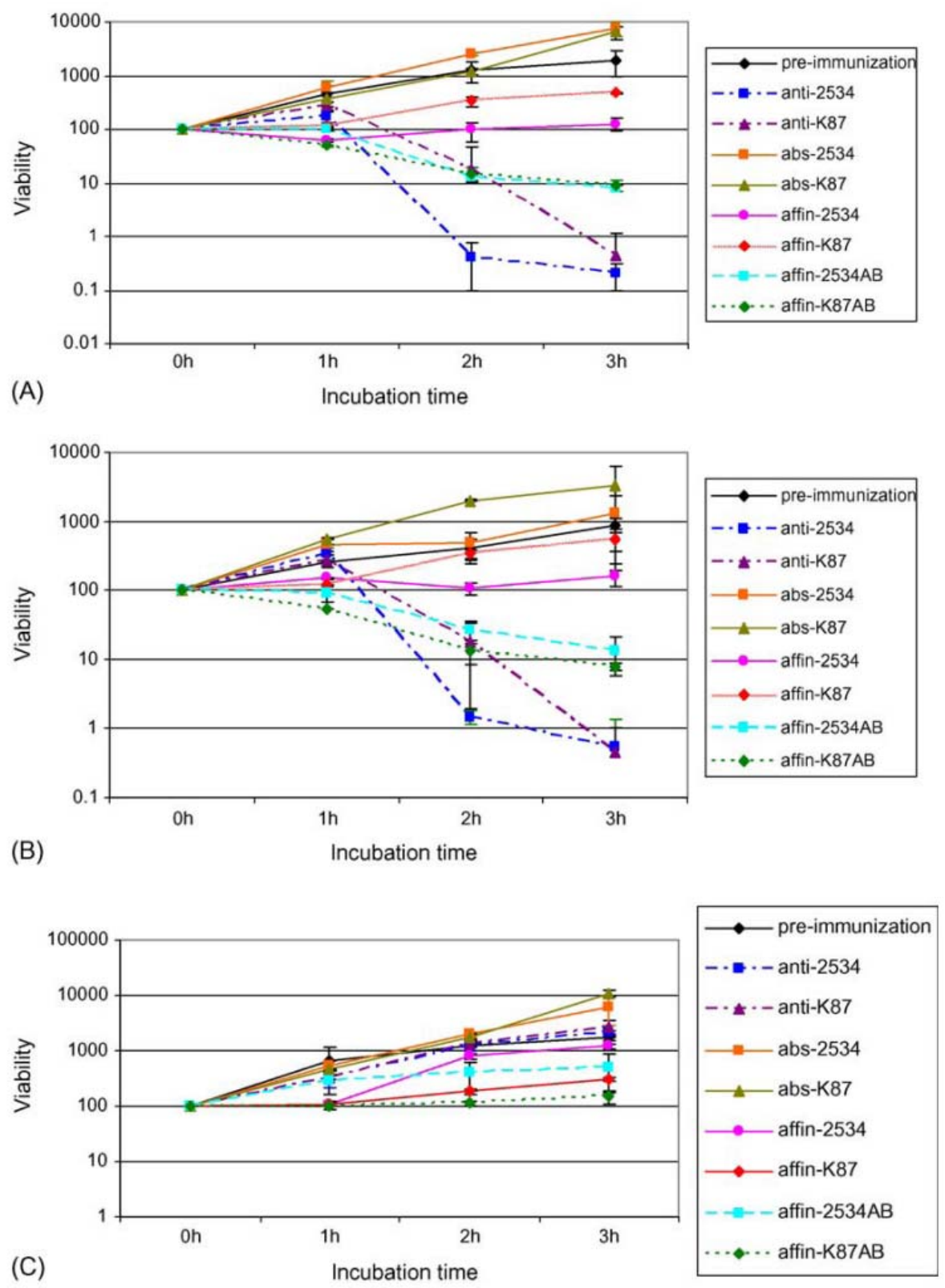

Figure 3. Bactericidal assay with antiserum from primary SPF pigs immunized with formalinized $E$. coli O8:K87 strain $2534-86$ cells $(n=3)$ or purified K87 polysaccharide (K87, $n=4)$. (A) Untreated serum; (B) Mg-EGTA-treated serum; (C) heat-inactivated serum. Pre-immunization: mean values of all pigs combined prior to immunization, anti-2534: serum from pigs immunized with 2534-86 cells, anti-K87: serum from pigs immunized with K87, abs-2534: serum from pigs immunized with 2534-86 cells and absorbed with 2534-86 cells, abs-K87: serum from pigs immunized with K87 and absorbed with 2534-86 cells, affin-2534: serum from pigs immunized with $2534-86$ cells and absorbed by affinity chromatography with beads coupled to K87, affin-K87: serum from pigs immunized with K87 and absorbed by affinity chromatography with beads coupled to K87, affin-2534AB: serum from pigs immunized with 2534-86 cells, absorbed by affinity chromatography with beads coupled to K87, and eluted anti-K87 antibodies from column added back to serum and affin-K87AB: serum from pigs immunized with K87, absorbed by affinity chromatography with beads coupled to K87, and eluted anti-K87 antibodies from column added back to serum. 
$>99 \%$ killing after $2 \mathrm{~h}$ incubation (Figure 3 ). The bactericidal activity of Mg-EGTA-treated sera in both groups was equivalent to that of untreated serum. These results suggested that killing activity occurred predominantly, if not exclusively by the alternative $\mathrm{C}$ pathway since EGTA chelates $\mathrm{Ca}^{2+}$, inactivating the classical $\mathrm{C}$ pathway, but has a lower affinity for $\mathrm{Mg}^{2+}$; the addition of $\mathrm{Mg}^{2+}$ allows the alternative pathway to proceed (Burns and Hull, 1998). Absorption of sera with 2534-86 cells completely removed bactericidal activity (Figure 3), whereas absorption of the same sera with formalinized strain F1321 (E. coli $\mathrm{O} 8: \mathrm{K}^{-}$) cells had no apparent effect (data not shown). Hence, specific antibodies are needed for bactericidal activity against $E$. coli $08: \mathrm{K} 87$. Sera from primary SPF pigs immunized with purified PP retained bactericidal activity against $E$. coli $\mathrm{DH} 5 \alpha$ following absorption with formalinized 2534-86 cells (data not shown), which confirmed that the absorption process had not eliminated the C-mediated bactericidal activity against serum-sensitive bacteria. Absorption by K87 affinity chromatography eliminated bactericidal activity, whereas absorption control sera from these same pigs had retained activity (Figure 3). Untreated and MgEGTA-treated absorbed sera from pigs immunized with either PP or 2534-86 cells complemented with eluted anti-K87 antibodies had restoration of killing activity (Figure 3). The anti-K87 titers of pre-absorbed serum and complemented serum were comparable (data not shown). Restoration of bactericidal activity in complemented serum confirmed the ability of anti-K87 antibodies to activate $\mathrm{C}$-mediated killing.

To determine whether antibodies other than antiK87 could activate killing of $2534-86$, bactericidal assays were conducted with serum from primary SPF agematched (68-72-day-old) control pigs lacking anti-K87 antibodies. This serum effected $>99 \%$ killing by $3 \mathrm{~h}$ incubation, and bactericidal activity of Mg-EGTA-treated serum was equivalent to that of untreated serum. The killing activity of age-matched control pig serum was eliminated by absorption with 2534-86 cells; however, it was not eliminated by K87 affinity chromatography (data not shown). These results indicated that specific antibodies other than anti-K87 can activate killing, although the antigen against which these non-capsular antibodies were directed was not addressed.

Since $\mathrm{Mg}^{2+}$ and $\mathrm{Ca}^{2+}$ are needed for the alternative and classical $\mathrm{C}$ pathways, respectively, to proceed, their concentrations in absorbed and non-absorbed sera from two primary SPF pigs tested in the bactericidal assays were determined. The $\mathrm{Mg}^{2+}$ and $\mathrm{Ca}^{2+}$ concentrations of non-absorbed sera of both pigs were within the normal range for porcine serum; however, concentrations of both cations in one of these sera after affinity chromatography were below the normal range. Addition of $\mathrm{MgCl}_{2}$ restored its bactericidal activity when complemented with eluted antibodies. By contrast, the $\mathrm{Mg}^{2+}$ and $\mathrm{Ca}^{2+}$ concentrations of the serum of the second pig, absorbed at a higher flow rate $(4 \mathrm{ml} / \mathrm{min})$, were within the normal range, indicating that the loss of bactericidal activity in affinity chromatography-absorbed serum was not due to an alteration in the concentration of these cations.

The ability of anti-capsular antibodies to activate alternative pathway killing of $E$. coli $\mathrm{O} 8: \mathrm{K} 87$ extends the observations reported by Hill et al. (1978). In that study, strain-specific antibodies activated alternative pathway killing of E. coli; however, bovine serum and a different serotype of $E$. coli were used, and the antigenic target was not identified. Interestingly, strains of the serotype used in that study (O149:K91) are typically enterotoxigenic, express F4 fimbria and are only known to cause natural disease in swine (Morris and Sojka, 1985). Similarly, anti-capsular antibodies, specifically of the $\operatorname{IgG}$ class, kill Haemophilus influenzae type B (Hib), in a process that occurs exclusively by the alternative pathway (Tarr et al., 1982); however, non-capsular antibodies are capable of $\mathrm{C}$ activation and killing of Hib, but this occurs exclusively by the classical pathway (Steele et al., 1984). Collectively, these studies suggest that alternative $\mathrm{C}$ pathway activation by anti-capsular antibodies may represent a common defense mechanism in mammalian species against encapsulated, serum-resistant Gram-negative bacteria. In the case of swine, anti-K87 antibodies appear to be highly prevalent, and we deduce that they may play an important role in host defense against ETEC-mediated post-diarrheal septicemia.

\section{Acknowledgements}

This study was funded by National Pork Producers Council grant \#99-104, USDA NRICGP grant 2004-35204-14915, and USDA CSREES Multi-State Research Project NC-1007. The authors thank Aruna Ambagala, Michael Carlson, Peter Kador, Subramaniam Srikumaran, Steve Tucker and Chris Whitfield for assistance. This work is a contribution of the University of Nebraska Agricultural Research Division, Lincoln (journal series no. 15114). 


\section{References}

Berberov et al., 2004: E.M. Berberov, Y. Zhou, D.H. Francis, M.A. Scott, S.D. Kachman and R.A. Moxley, Relative importance of heat-labile enterotoxin in the causation of severe diarrheal disease in the gnotobiotic piglet model by a strain of enterotoxigenic Escherichia coli that produces multiple enterotoxins, Infect. Immun. 72 (2004), pp. 3914-3924.

Burns and Hull, 1998: S.M. Burns and S.I. Hull, Comparison of loss of serum resistance by defined lipopolysaccharide mutants and an acapsular mutant of uropathogenic Escherichia coli O75: K5, Infect. Immun. 66 (1998), pp. 4244-4253.

Gross and Rowe, 1985: R.J. Gross and B. Rowe, Serotyping of Escherichia coli. The virulence of Escherichia coli: review and methods. In: M. Sussman, Editor, Society for General Microbiology, Academic Press, Orlando, FL (1985), pp. 345-363.

Hill et al., 1978: A.W. Hill, A.L. Shears and K.G. Hibbitt, The requirement of specific antibody for the killing of $E$. coli by the alternate complement pathway in bovine serum, Immunology 34 (1978), pp. 131-136.

Jann, 1985: K. Jann, Isolation and characterization of capsular polysaccharides (K antigens) from Escherichia coli. The virulence of Escherichia coli: review and methods. In: M. Sussman, Editor, Society for General Microbiology, Academic Press, Orlando, FL (1985), pp. 375-379.

Meier and Mayer, 1985: U. Meier and H. Mayer, Genetic location of genes encoding enterobacterial common antigen, J. Bacteriol. 163 (1985), pp. 756-762.
Morris and Sojka, 1985: J.A. Morris and W.J. Sojka, Escherichia coli as a pathogen in animals. The virulence of Escherichia coli: review and methods. In: M. Sussman, Editor, Society for General Microbiology, Academic Press, Orlando FL (1985), pp. 47-77.

Parolis et al., 1990: H. Parolis, L.A.S. Parolis and S.M.R. Stanley, The structure of the capsular antigen from Escherichia coli O8: K87:H19, Carbohydr. Res. 205 (1990), pp. 361-370.

Saha and Brewer, 1994: S.K. Saha and C.F. Brewer, Determination of the concentration of oligosaccharides, complex type carbohydrates, and glycoproteins using the phenol-sulfuric acid method, Carbohydr. Res. 254 (1994), pp. 157-167.

Stawski et al., 1990: G. Stawski, L. Nielsen, F. Orskov and I. Orskov, Serum sensitivity of a diversity of Escherichia coli antigenic reference strains, Acta Pathol. Microbiol. Immunol. Scand. 98 (1990), pp. 828-838.

Steele et al., 1984: N.P. Steele, R.S. Munson Jr., D.M. Granoff, J.E. Cummins and R.P. Levine, Antibody-dependent alternative pathway killing of Haemophilus influenzae type b, Infect. Immun. 44 (1984), pp. 452-458.

Tarr et al., 1982: P.I. Tarr, S.W. Hosea, E.J. Brown, R. Schneerson, A. Sutton and M.M. Frank, The requirement of specific anticapsular IgG for killing of Haemophilus influenzae by the alternative pathway of complement activation, J. Immunol. 128 (1982), pp. $1772-1775$. 